\title{
PERLINDUNGAN HUKUM TERHADAP PEREMPUAN KORBAN KEKERASAN DALAM RUMAH TANGGA DALAM SISTEM PERADILAN PIDANA DI KOTA JAMBI
}

\author{
Ferdricka Nggeboe ${ }^{1}$
}

\begin{abstract}
The marriage bond that is conducted aims to form a happy prosperous household, eternal and lasting under the protection of God Almighty, with the aim, automatically the family should be fostered as well as possible, mutual love and affectionate love between husband and wife and children. Each couple wishes for a harmonious married life, but not forever the condition of the household between husband and wife good and peaceful, because sometimes there are quarrels and bickering, which often leads to the occurrence of violence in the household that eventually happened to a percerarian. The legal policy issued by the Government of the Republic of Indonesia to anticipate violence especially domestic violence is Law Number 23 Year 2004 on the Elimination of Domestic Violence (PKDRT). This law is expected to reveal the various violations in the household and the protection of the rights of victims of violence without exception, therefore the question to be answered in this study is, How to protect the law against women victims of domestic violence in the criminal justice system in the City Jambi. This research uses empirical juridical type, and as its analysis knife the researcher uses legal protection theory, that is preventive law protection and repressive law protection. The emphasis of the analysis on the fact that repressive legal protection in the criminal justice system is reflected from the case reporting process until the case is decided by the judge in court. In addition to a brief overview of the process of domestic violence in the criminal justice system, there are also some judges' decisions on cases with free decisions and verdicts stating that the case was revoked. That the repressive legal protection of victims of domestic violence through the decision of a court of a criminal verdict has shown the comparison of law, although it is still far from the legal certainty.
\end{abstract}

Keywords: Legal Protection Against Women, Domestic Violence Victims, Criminal Justice System

\section{PENDAHULUAN}

Berdasarkan Pasal 1 UndangUndang Nomor 1 Tahun 1974 tentang Perkawinan bahwa tujuan perkawinan adalah untuk membentuk keluarga atau rumah tangga yang bahagia dan kekal berdasarkan Ketuhanan Yang Maha Esa. Rumah tangga adalah organisasi terkecil dalam kehidupan masyarakat yang terdiri dari ayah dan ibu sebagai suami istri dan anak-anaknya.

Interaksi antara suami, istri dan anak-anaknya dalam kehidupan

\footnotetext{
${ }^{1}$ Dosen Magister Hukum Universitas Batanghari Jambi
}

rumah tangga, yang didasarkan pada Ketuhanan Yang Maha Esa seharusnya mampu menciptakan kehidupan rumah tangga yang bahagia. Kenyataannya masih banyak terjadinya kekerasan dalam kehidupan rumah tangga. Padahal setiap insan manusia dalam rumah tangga berhak mendapatkan rasa aman dan bebas dari segala bentuk kekerasan sebagai bagian dari hak asasi manusia.

Pertengkaran-pertengkaran

dalam rumah tangga yang selalu berakhir dengan kekerasan akan merugikan salah satu pihak yang 
menjadi korbannya, yang pada umumnya adalah isteri dan/atau anak-anak. Sedangkan kekerasan dalam rumah tangga yang terjadi tidak saja menyiksa perasaan korban (psikis), melainkan juga merusak fisik korban dan malah ada korban yang cacat seumur hidup maupun sampai meninggal dunia.

Kebijakan hukum yang dikeluarkan oleh pemerintah Republik Indonesia untuk mengantisipasi tindak kekerasan terkhusus kekerasan dalam rumah tangga adalah Undang-undang Nomor 23 Tahun 2004 tentang Penghapusan Kekerasan Dalam Rumah Tangga (PKDRT). Undangundang ini diharapkan dapat mengungkap berbagai kekerasan dalam rumah tangga serta terlindunginya hak-hak korban kekerasan tanpa terkecuali di mana saja.

Adapun hak-hak korban kekerasan yang dilindungi menurut ketentuan Pasal 10 Undang-undang Nomor 23 Tahun 2004 adalah berupa

a. Perlindungan dari pihak keluarga, kepolisian, kejaksaan, pengadilan, advokat, lembaga sosial, atau pihak lainnya baik sementara maupun berdasarkan penetapan perintah perlindungan dari pengadilan;

b. Pelayanan kesehatan sesuai dengan kebutuhan medis;

c. Penanganan secara khusus berkaitan dengan kerahasiaan korban;

d. Pendampingan oleh pekerja sosial dan bantuan hukum pada setiap tingkat proses pemeriksaan sesuai dengan ketentuan peraturan perundang-undangan; dan

e. Pelayanan bimbingan rohani.

Setelah dikeluarkannya Undang-undang Nomor 23 Tahun 2004 tersebut di atas, sudah banyak kasus-kasus kekerasan rumah tangga yang masuk ke Kepolisian Resort Kota Jambi, Adapun kasus tindak pidana kekerasan rumah tangga yang dilaporkan pada tahun 2015 sebanyak 40 kasus, pada tahun 2016 ada 34 kasus dan sampai Juli 2017 sebanyak 20 kasus.

Penegakan hukum terhadap Kekerasan Dalam Rumah Tangga pada kenyataannya, sangat dimungkinkan dalam pelaksanaannya menghadapi berbagai permasalahan, Disinyalir banyaklah kasus kekerasan dalam rumah tangga tidak sampai diselesaikan ke Pengadilan. Namun demikian, jika ada kasus tindak pidana kekerasan dalam rumah tangga yang masuk ke Pengadilan Negeri Jambi dan terhadap kasus tersebut hakim harus bijaksana dan berani untuk tetap memeriksa dan mengadili perkaranya.

Kekerasan dalam rumah tangga menurut Pasal 1 UndangUndang Nomor 23 Tahun 2004 tentang penghapusan Kekerasan Dalam Rangga, sebenarnya adalah setiap perbuatan terhadap seseorang terutama perempuan yang berakibat timbulnya kesengsaraan atau penderitaan secara fisik, seksual, dan atau penelantaran rumah tangga termasuk ancaman untuk melakukan perbuatan, pemaksaan, atau perempasan kemerdekaan secara melawan hukum (onrechtmagtigedaad) dalam lingkup rumah tangga.

Laporan Rijka Annisa

Women's Centre menyatakan bahwa : Dari beberapa kasus pengaduan yang datang ke kami, yang terbanyak sehingga mencapai $70 \%$ adalah perempuan korban kekerasan suami. Bahkan ada kekerasan yang sampai 
berakibat kebutaan, dan cacat lainnya, sampai pada kematian, tetapi ironisnya hanya $2 \%$ saja yang bersedia membawa kasusnya, baik ke pengadilan maupun melapor ke Kepolisian. $^{2}$

Selain itu 'Banyaknya kasus yang tidak dilaporkan ke kepolisian atau sampai ke meja hijau karena masih adanya pandangan yang bersifat patriaki ${ }^{3}$. Patriarki adalah budaya yang menempatkan laki-laki sebagai yang utama atau superior dibandingkan dengan perempuan yang memandang urusan rumah tangga adalah urusan pribadi yang tidak boleh dicampuri oleh orang lain.

\section{Rumusan Masalah}

Berdasarkan hal tersebut maka terdapat pertanyaan "Bagaimanakah Perlindungan Hukum Terhadap Perempuan Korban Kekerasan Dalam Rumah Tangga Dalam Sistem Peradilan Pidana di Kota Jambi"?

\section{METODE PENELITIAN}

Spesifikasi penelitian ini adalah bersifat yuridis sosiologis dengan pertimbangan bahwa titik tolak penelitian ini adalah peraturan perundang-undangan yang mengatur tentang perlindungan terhadap korban dalam lingkup kekerasan dalam rumah tangga serta penerapannya di lapangan, dengan pendekatan diskriptif analitis, yaitu memaparkan, menggambarkan atau mengungkapkan penerapan ketentuan perundang-undangan mengenai perlindungan terhadap korban kekerasan dalam rumah tangga.

2 'Rika Saraswati, Perempuan dan PenyeMsaian Kekerasan Dalam Rumah Tangga, Bandung; Citra Adytia, 2006, hal. 2.

$$
{ }^{3} \text { jbid, hal. } 3
$$

PEMBAHASAN

Perlindungan Hukum Terhadap

Perempuan Korban Kekerasan

Dalam Rumah Tangga Dalam

Sistem Peradilan Pidana di Kota Jambi

Konsep perlindungan hukum sebenarnya di awali dengan adanya pengakuan terhadap hak-hak asasi manusia, perlindungan hukum menurut UU no 23 Tahun 2004 yang bertujuan untuk melindungi subjeksubjek hukum dalam hal ini subjeksubjek hukum dalam UU No 23 Tahun 2004 yang menjadi korban kekerasan adalah semua orang yang berada dalam lingkup Rumah Tangga tersebut, baik yang ada dalam hubungan perkawinan, hubungan darah, maupun dalam hubungan pekerjaan, Korban KDRT bisa saja terjadi pada laki-laki sebagai suami bisa juga anak baik laki-laki maupun perempuan, orang tua, saudara ataupun pembantu Rumah Tangga namun dalam hal ini, peneliti hanya membatasi pembahasan terhadap korban kekerasan yang subjek hukumnya adalah perempuan.

Dilandasi ketentuan Pasal 5 sampai dengan Pasal 9 Undangundang Nomor 23 Tahun 2004, yang tergolong kekerasan dalam rumah tangga terdiri atas 4 (empat) jenis, yaitu sebagaimana terurai sebagai berikut :

1. Kekerasan Fisik

Adalah suatu perbuatan yang mengakibatkan rasa sakit, jatuh sakit atau luka berat (Pasal 6). Jadi kekerasan fisik ini adalah tindakan yang berakibat sakitnya tubuh korban tindak pidana.

2. Kekerasan Psikis Adalah perbuatan yang mengakibatkan ketakutan, hilangnya rasa percaya diri, hilangnya kemampuan untuk bertindak, rasa tidak berdaya,

Perlindungan Hukum terhadap Perempuan Korban Kekerasan dalam Rumah Tangga dalam Sistem Peradilan Pidana di Kota Jambi 
dan/atau penderitaan psikis berat pada seseorang (Pasal 7).

3. Kekerasan Seksual Adalah perbuatan yang meliputi :

a. Pemaksaan hubungan seksual yang dilakukan terhadap orang yang menetap dalam lingkup rumah tangga tersebut; atau

b. Pemaksaan hubungan seksual terhadap salah seorang dalam lingkup rumah tangga dengan orang lain untuk tujuan komersial dan/atau tujuan tertentu (Pasal 8).

Menurut penjelasan Pasal 8 Undang-undang Nomor 23 Tahun 2004 mengenai kekerasan seksual ini adalah sebagai berikut :

Yang dimaksud dengan kekerasan seksual dalam ketentuan ini adalah setiap perbuatan yang berupa pemaksaan hubungan seksual, pemaksaan hubungan seksual dengan cara tidak wajar dan/atau tidak disukai, pemaksaan hubungan seksual dengan orang lain untuk tujuan komersial dan/atau tujuan tertentu.

4. Penelantaran Rumah Tangga

Mengenai tindakan ini dalam Pasal 9 Undang-undang Nomor 23 Tahun 2004 menentukan :

Setiap orang dilarang menelantarkan orang dalam lingkup rumah tangganya, padahal menurut hukum yang berlaku baginya atau karena persetujuan atau perjanjian ia wajib memberikan kehidupan, perawatan atau pemeliharaan kepada orang tersebut. Penelantaran sebagaimana dimaksud ayat (1) juga berlaku bagi setiap orang yang mengakibatkan Jadi tindakan penelantaran rumah tangga ini adalah berupa : a. Tidak memberikan kehidupan bagi korban;

b. Tidak memberikan perawatan kepada korban;

c. Tidak melakukan pemeliharaan terhadap korban; atau

d. Membatasi dan/atau melarang korban untuk bekerja yang layak di dalam atau di luar rumah.

ketergantungan ekonomi dengan cara membatasi dan/atau melarang untuk bekerja yang layak di dalam atau di luar rumah sehingga korban berada di bawah kendali orang tersebut.

Dijadikannya Undang-undang Nomor 23 Tahun 2004 ini sebagai dasar hukum kekerasan rumah tangga dilandasi dari pertimbangan pengeluaran undang-undang itu sendiri, yang berisikan :

a. Bahwa setiap warga negara berhak mendapatkan rasa aman dan bebas dari segala bentuk kekerasan sesuai dengan falsafah Pancasila dan Undang-Undang Dasar Negara Republik Indonesia Tahun 1945.

b. Bahwa segala bentuk kekerasan, terutama kekerasan dalam rumah tangga, merupakan pelanggaran hak asasi manusia dari kejahatan terhadap martabat kemanusiaan serta bentuk diskriminasi yang harus dihapus.

c. Bahwa korban kekerasan dalam rumah tangga, yang kebanyakan adalah perempuan, harus mendapat perlindungan dari negara dan/atau masyarakat agar terhindar dan terbebas dari kekerasan atau ancaman kekerasan, peyiksaan atau perlakuan yang merendahkan derajat dan martabat kemanusiaan.

d. Bahwa dalam kenyataannya, kasus kekerasan dalam rumah tangga banyak terjadi, sedangkan 
sistem hukum di Indonesia belum menjamin perlindungan terhadap kekerasan dalam rumah tangga.

e. Bahwa berdasarkan pertimbangan sebagaimana dimaksud dalam huruf $a$, huruf $b$, huruf $c$, dan huruf $\mathrm{d}$, perlu dibentuk Undangundang tentang penghapusan kekerasan dalam rumah tangga.

Perlindungan hukum pada dasarnya dapat dibedakan dalam dua (2) macam tujuan yaitu, perlindungan hukum yang bersifat preventif dan perlindungan hukum yang bersifat Represif ataupun perlindungan hukum yang bersifat Preventif bertujuan untuk mencegah sebelum terjadinya pelanggaran, subjek-subjek hukum diharapkan untuk mewaspadai kondisi-kondisi yang dapat memicu terjadinya korban. Tindakan pencegahan ini dimaksudkan bahwa subjek-subjek hukum harus menyadari potensi yang dapat menjadikan dirinya sebagai korban.

Sebagaimana Teori Penegakan Hukum yang disampaikan oleh Satjipto Raharjo bahwa hukum itu melindungi kepentingan seseorang dengan cara mengalokasikan suatu kekuasaan kepadanya untuk bertindak dalam rangka kepentingannya tersebut. Hal ini artinya membuka pemahaman bahwa mengalokasikan kekuasaan kepadanya untuk bertindak, ini berhubungan dengan hak. Hak yang tentunya dijamin oleh aturan hukum.

Kekerasan yang terjadi dalam Rumah Tangga sebagaimana yang tercatat pada KePolisian Resort Kota Jambi (Polresta) maka di dapatlah sebagai data pada Tabel I dibawah ini :

\section{Tabel I}

Jumlah Perkara KDRT

Di Polresta Jambi

\begin{tabular}{cccccc}
\hline No & Tahun & $\begin{array}{c}\text { Jumlah } \\
\text { Perkara }\end{array}$ & Proses & $\begin{array}{c}\text { Penyelesaian } \\
\text { Diteruskan }\end{array}$ & Dihentikan \\
\hline 1 & 2015 & 40 & 2 & 21 & 17 \\
2 & 2016 & 34 & 3 & 18 & 13 \\
3 & Juli 2017 & 20 & 5 & 9 & 6 \\
\hline
\end{tabular}

Sumber Data POLRESTA JAMBI

Selanjutnya didapat pula gambaran tentang perkara kekerasan dalam rumah tangga yang naik

sampai ke Pengadilan Negeri Jambi sebagaimana yang terdapat pada Tabel II di bawah ini :

\section{Tabel II}

Jumlah Perkara KDRT

Di Pengadilan Negeri Jambi

\begin{tabular}{ccccc}
\hline \multirow{2}{*}{ No } & \multirow{2}{*}{ Tahun } & \multirow{2}{*}{ Jumlah Perkara } & \multicolumn{2}{c}{ Status Perkara } \\
& & & Putus & Proses \\
\hline 1 & 2015 & 21 & 19 & 2 (Kasasi) \\
2 & 2016 & 18 & 17 & 1 (Kasasi) \\
3 & Juli 2017 & 9 & 5 & 4 (Proses) \\
\hline
\end{tabular}

Sumber Data PN Jambi

Gambaran tentang Kekerasan Dalam Rumah Tangga di atas secara fenomenal merupakan Gunung es, dimana para perempuan harus di dampingi atau diberikan semangat keberanian untuk melaporkan perkaranya kepada pihak penegak hukum. Kondisi yang tampak, 
senyatanya belumlah mengungkap secara keseluruhan perkara Kekerasan Dalam Rumah Tangga (KDRT) yang terjadi dalam masyarakat. masih banyak perempuan dan anak-anak yang menjadi korban KDRT masa takut untuk mengadukan perkaranya pada pihak berwajib .Ibu Ulfah dari Koalisi Perempuan Indonesia 'menyatakan bahwa perempuan dan anak yang datang ke kantor untuk mengadukan permasalahan yang dihadapinya pada tahun 2016 berjumlah 20 orang sedangkan sampai Juli 2017 sudah ada 10 perkara, Jumlah perkara ini mungkin saja akan meningkat, namun harapan kita angka tersebut cukuplah sampai di situ saja ${ }^{4}$.

Perbedaan yang terjadi dari ketiga macam Institusi tersebut mengundang tanya sehingga peneliti tertarik untuk menganalisanya lebih lanjut, Koalisi Perempuan Indonesia yang ada di Jambi ini merupakan salah satu organisasi sosial masyarakat yang mengurusi masalah perempuan. Di Jambi terdapat banyak organisasi semacam ini yang sumber utamanya adalah Badan Pemberdayaan Perempuan Milik Pemerintah. Perempuan-perempuan yang datang pada organinasi sosial untuk menyampaikan permasalahan yang mereka hadapi kebanyakan masih masih tetap berupaya untuk menyelamatkan Rumah Tangganya dari kondisi yang lebih buruh lagi, mengingat jika suami-suami mereka di laporkan kepada pihak yang bewajib untuk mempertanggungjawabkan

perbuatannya, seringkali justru akan menambah sikap emosional pelaku kekerasan dalam Rumah Tangga (KDRT) yang tidak jarang akhirnya

4 Ibu Ulfah, Ketua Koalisi Perempuan Indonesia Jambi wawancara 27 Juli 2017 berujung pada putusan perceraian, hanya sedikit sekali, pelaku yang mau berdamai dengan menyesali perbuatannya, hal ini tergambar dari syarat perdamaian yang diajukan oleh kedua belah pihak ketika perkaranya masih sebagai laporan ke Kepolisian.

Bripka Alamsyah F W, SH salah satu penyidik di Kepolisian Resort Kota Jambi memberikan penjelasan bahwa dari beberapa perkara yang dihentikan dan dicabut kerena adanya perdamaian, hanya beberapa pelaku saja yang menyetujui isi perjanjian perdamaiannya 'bahwa pelaku menyesali perbuatannya sehingga akan berupaya untuk memperbaiki kehidupan Rumah Tangganya, sedangkan ada yang lainnya, yaitu isi perjanjian perdamaian adalah pelaku setuju untuk bercerai ${ }^{5}$, kondisi sosial masyarakat seperti ini memang menyedihkan, meningkatnya kasus perceraian sebagaimana data yang peneliti dapatkan dari Pengadilan Agama Jambi di diskripsikan pada tabel III di bawah ini :

\section{Tabel III}

Perkara Cerai di Pengadilan Agama Jambi

\begin{tabular}{ccccc}
\hline \multirow{2}{*}{ No } & \multirow{2}{*}{ Tahun } & Jumlah & \multicolumn{2}{c}{ Putusan } \\
& & Perkara & Gugat & Talak \\
\hline 1 & 2015 & 1121 & 865 & 256 \\
2 & 2016 & 1088 & 827 & 261 \\
3 & Juli & 516 & 394 & 122 \\
\hline
\end{tabular}

Sumber Data PA Jambi

Berapa alasan mengapa perempuan-perempuan (istri) lebih memilih keputusan untuk bercerai, tidak lain karena merasa sudah tidak aman dan nyaman tinggal serumah bersama suaminya, ketakutan akan terulang kembali perbuatan pelaku menjadi ancaman sehingga

5 Bripka Alamsyah F. W. SH., Penyidik Polresta Jambi, Wawancara 25 Juli 2017

Perlindungan Hukum terhadap Perempuan Korban Kekerasan dalam Rumah Tangga dalam Sistem Peradilan Pidana di Kota Jambi 
perempuan tersebut memilih untuk hidup berpisah, namun dari beberapa perkara ada juga dimana sang istri mau menerima kembali suami yang telah menganiayanya dalam kehidupan Rumah Tangga mereka, tentunya perempuan tersebut masih menyimpan harapan kalau suami (pelaku KDRT) menginsafi perbuatannya dan tidak mengulangi lagi perbuatan tersebut.

Perbedaan jumlah data sebagaimana yang terdapat dari ketiga instansi di atas (Polresta, PN Jambi, KPI) dapatlah peneliti jelaskan bahwa :

1. Nama-nama perempuan yang mendatangi Koalisi Perempuan Indonesia hanya sebahagian kecil yang meneruskan perkaranya untuk di tindak lanjuti oleh Pihak Kepolisian.

2. Jumlah perkara yang masuk ke kepolisian lebih banyak dari jumlah perkara yang masuk kepengadilan, ini disebabkan karena perkara yang masuk kepolisian, sebahagian diselesaikan secara non penal melalui perdamaian kedua belah pihak, dimana akhirnya perkara tersebut di cabut sehingga kasusnya ditutup.

Sebagai perkara yang termasuk delik aduan, kekerasan dalam rumah tangga ini masih di pandang masyarakat bersifat domestic violent, orang lain enggan untuk turut camput menyelesaikan masalah, jika kondisi perempuan masih belum serius, dan jika terdapat akibat yang fatal sampai pada kematian korban berulah masyarakat turut campur dan memperlihatkan kepeduliannya terhadap masalah ini, Hal ini sungguh sangat disayangkan, sebagai perempuan dan anak yang memiliki kedudukan yang lemah tentunya perlu pula mendapatkan pertolongan segera jika terjadi perkara KDRT, bagaimana kita mengetahui bahwa telah terjadi kekerasan dalam rumah tangga sementara pintu rumah tertutup ?

Dilematis perempuan (istri) jika terjadi kekerasan dalam rumah tangga padanya, jika dilaporkan ke pihak yang berwajib sehingga diketahui oleh umum, adalah hal yang dapat digolongkan sebagai istilah menempuk air didulang terpecik muka sendiri, rasa sakit, rasa malu, rasa kesal, rasa takut semua beradu menjadi satu, keinginan untuk melapor agar pelaku dapat mempertanggungjawabkan

perbuatannya, atau menyimpan saja kejadian yang terjadi karena rasa malu jika diketahui orang, merupakan suatu satu keputusan yang berat, apalagi hubungan yang terjadi diantara mereka adalah atas dasar cinta.

Hadirnya Undang-undang No 23 Tahun 2004 sebenarnya sudah cukup membantu agar perempuan , menyadari akan hak dan kedudukanya dalam masyarakat khusus dalam keluarga, sikap tegas menolak tindakan kekerasan adalah langkah tepat agar dapat menjadi shock terapy bagi pelaku, sehingga harus berfikir (dua) kali untuk melakukan tindakan kekerasan.

Pelaku atau korban KDRT adalah orang yang mempunyai hubungan darah, perkawinan, persusuan, pengasuhan, perwalian dengan suami, dan anak bahkan pembatu rumah tangga, tinggal di rumah ini. Ironisnya kasus KDRT sering ditutup-tutupi oleh si korban karena terpaut dengan struktur budaya, agama dan sistem hukum yang belum dipahami. Perlindungan yang bersifat preventif bertujuan untuk mencegah sebelum terjadinya pelanggaran-pelanggaran aturan, subjek hukum diharapkan untuk mewaspadai kondisi-kondisi yang 
dapat memicu terjadinya korban. Tindakan pencegahan ini dimaksudkan bahwa subjek-subjek hukum harus menyadari potensi yang dapat menjadikan dirinya sebagai korban tindak kekerasan atau kejahatan. Sikap tegas perempuan yang berani melawan tindakan kekerasan akan dapat melindungi dirinya sendiri.

Perlindungan hukum yang bersifat Represif ( pencegahan khusus) yaitu berupa tindakan dengan mengenakan sanksi kepada pelaku yang melanggar hukum. Perlindungan hukum terhadap korban di wakilkan kepada aparat yang diberi wewenang untuk menindak pelaku berdasarkan aturan hukum yang tersedia untuk itu, Berbicara dalam kapasitas Sistem Peradilan Pidana, maka kewenangan aparat yang dimaksud yang dapat memproses pertanggungjawaban pelaku adalah Kepolisian, Kejaksaan, Hakim dan Petugas Lembaga Pemasyarakatan.

Perlindungan hukum yang bersifat perventif secara umum tidak perlu menggunakan banyak biaya, sedangkan perlidungan hukum yang bersifat represif tentunya negara akan banyak mengeluarkan biaya, yang hasilnya belum tentu dapat merubah prilaku pelaku menjadi lebih baik, Peneliti dalam menyampaikan hal ini tentunya di dasarkan banyaknya pelaku yang menjadi residivis, walaupun bukan dalam perkara Kekerasan Dalam Rumah Tangga (KDRT).

Perlindungan hukum yang bersifat represif, yaitu merupakan perlidungan secara tidak langsung dengan memberikan tanggungjawab yang berupa sanksi, seperti denda, penjara atau hukuman tambahan yang diberikan kepada pelaku yang sudah melanggar suatu aturan khususnya UU No. 23 Tahun 2004, tentang Kekerasan Dalam Rumah Tangga. Mengenai hukuman yang diberikan kepada pelaku dari beberapa perkara sebagai yang terdapat pada Tabel II, secara lebih rinci peneliti akan mendiskripsikannya pada Tabel IV sampai Tabel VI dibawah ini :

\section{Tabel IV}

Pelaku KDRT Tahun 2015 Di PN Jambi

\begin{tabular}{|c|c|c|c|c|}
\hline \multirow{2}{*}{ No } & \multirow{2}{*}{ No. Perkara } & \multirow{2}{*}{ Klasifikasi Perkara } & \multicolumn{2}{|l|}{ Status Perkara } \\
\hline & & & ahapan & Status \\
\hline 1 & 16/Pid.sus/2015 & $\begin{array}{l}\text { Pasal } 49 \text { Huruf a UU No } 23 \text { Tahun } \\
2004\end{array}$ & Putusan 7 bulan penjara & Inkrah \\
\hline 2 & 19/Pid.sus/2015 & Pasal 49 Huruf a & Putusan 8 bulan & Inkrah \\
\hline 3 & 40/Pid.sus/2015 & Pasal 44 (1) (4) UU No 23/2004 & Putusan 3 bulan & Inkrah \\
\hline 4 & 43/Pid.sus/2015 & Pasal 44 (1) (4) UU No 23/2004 & Putusan 4 bulan & Inkrah \\
\hline 5 & 46/Pid.sus/2015 & Pasal 49 huruf a UU No 23/2004 & Bebas & Inkrah \\
\hline 6 & 219/Pid.sus/2015 & Pasal 44 (1) (4) UU No 23/2004 & Putusan 1 Tahuun & Inkrah \\
\hline 7 & 223/Pid.sus/2015 & Pasal 44 (1) (4) UU No 23/2004 & Putusan 4 bulan penjara & Inkrah \\
\hline 8 & 258/Pid.sus/2015 & Pasal 44 (1) (4) UU No 23/2004 & Putusan 10 bulan & Inkrah \\
\hline 9 & 320/Pid.sus/2015 & Pasal 44 (1) (4) UU No 23/2004 & Putusan 1 Tahun & Inkrah \\
\hline 10 & 346/Pid.sus/2015 & Pasal 44 (1) (4) UU No 23/2004 & Putusan 7 bulan penjara & Inkrah \\
\hline 11 & 393/Pid.sus/2015 & Pasal 44 (1) (4) UU No 23/2004 & Putusan 8 bulan penjara & Inkrah \\
\hline 12 & 394/Pid.sus/2015 & Pasal 44 (1) dan Pasal 351 KUHP & $\begin{array}{l}\text { Putusan } 1 \text { Tahun } 4 \text { bulan } \\
\text { penjara }\end{array}$ & Inkrah \\
\hline 13 & 432/Pid.sus/2015 & Pasal 44 (1) (4) UU No 23/2004 & Putusan 3 bulan penjara & Inkrah \\
\hline 14 & 559/Pid.sus/2015 & Pasal 44 (1)dan Pasal 45 (1) & Putusan 6 bulan penjara & Inkrah \\
\hline 15 & 579/Pid.sus/2015 & Pasal 44 (1) (4) UU No 23/2004 & Putusan 10 bulan penjara & Inkrah \\
\hline 16 & 616/Pid.sus/2015 & Pasal 44 (1) (4) UU No 23/2004 & Putusan 1 Tahun penjara & Inkrah \\
\hline 17 & 642/Pid.sus/2015 & Pasal 44 (1) (4) UU No 23/2004 & Putusan 3 bulan 15 Hari & Inkrah \\
\hline
\end{tabular}


18 643/Pid.sus/2015 Pasal 44 (1) (4) UU No 23/2004

19 718/Pid.sus/2015 Pasal 44 (1) (4) UU No 23/2004

20 728/Pid.sus/2015 Pasal 44 (1) dan pasal 531 KUHP

21 778/Pid.sus/2015 Pasal 44 (1) (4) UU No 23/2004
Putusan 2 bulan penjara

Putusan 6 bulan penjara

Putusan 10 bulan penjara

Putusan 4 bulan penjara
Inkrah

Inkrah

Inkrah

Inkrah
Penjatuhan hukuman terhadap pelaku sebagaimana terlihat pula tabel 4 di atas menunjukkan bahwa terdapat variasi putusan hakim sebagai bentuk pertanggungjawaban pelaku atau kesalahan yang dilanggarnya. Menilik pada aturan yang digunakan untuk menyeret Pelaku dalam putusan Pengadilan Negeri Jambi tersebut, adalah Pasal 44, Pasal 45, Pasal 49 UU No. 23 Tahun 2004 dan Pasal 351 Kitab UU Hukum Pidana (KUHP).

Undang-Undang No. 23 tahun 2004 tidak memiliki straf minimal (ancaman minimal) dan straf maksimal (ancaman maksimal). Contoh ancaman yang teringan dalam UU. 23 tahun 2004 adalah sebagaimana yang terdapat dalam Pasal 44 ayat (4), yaitu hanyalah 4 (empat) bulan penjara. Namun terhadap perbedaan yang sangat signifikan ketika ancaman hukuman maksimal 5 (lima) tahun dalam Pasal 44 ayat (1) putusan hakim rata-rata di bawah 1 (satu) tahun begitupula dalam Pasal 45 (1) dalam Pasal 49 ancaman maksimalnya adalah 3 (tiga) tahun penjara, Putusan hakim yang telah dijatuhkan peneliti tidak menemukan adanya pidana denda, memang mengenai acaman pidana denda merupakan penjatuhan putusan yang bersifat alternatif, yaitu boleh memilih pidana penjara atau pidana denda. Peneliti melihat secara keseluruhan putusan yang dijatuhkan masih belum menunjukkan adanya kepastian hukum, yang hendak dicapai dalam penjatuhan hukuman ini adalah bentuk kesebandingan hukum, namun hal ini tidak akan peneliti bahas lebih lanjut tentang bagaimana pertimbangan hakim sehingga telah menjatuhkan hukuman tersebut.

Selain Pasal 44 UU No. 23 Tahun 2004 tentang PKDRT ternyata pelaku mempertanggungjawabkan

perbuatannya juga dijerat dengan Pasal 351 KUHP. sebagaimana telah di ketahui bahwa UU NO. 23 Tahun 2004 merupakan Lex specialis dari Pasal 531
KUHP. Setiap pelaku kekerasan dalam Rumah Tangga dapat dijerat dengan undang-undang ini jika pelakunya memiliki hubungan perkawinaan yang sah dan tercatat di KUA ( Kantor Urusan Agama) atau dicatatan Sipil alias mempunyai buku nikah resmi.

Jika suami atau istri atau anak dalam suatu rumah tangga : menjadi korban KDRT namun perkawinan mereka tidak dicatat secara resmi atau dengan kata lain nikah di bawah tangan, dalam masyarakat biasa menyebutnya sebagai nikah sirih, perkara yang diajukan ke Pengadilan oleh Jaksa Penuntut Umum adalah dengan dakwaan/tuntutan bahwa pelaku di jerat dengan Pasal 351 KUHP. Hal ini sebagaimana yang disampaikan oleh Rama Triranti, SH. bahwa dalam pernikahan siri, kami tetap mendakwa pelaku kekerasan dengan UU No. 23 Tahun 2004, namun yang dapat di buktikan di Pengadilan adalah pasal 351 KUHP.

Hal senada apa yang disampaikan Jaksa Penuntut Umum di dukung pula dengan pendapat ibu Sri Warni Wati, SH. MH, hakim Pengadilan Negeri Jambi yang menyebutkan bahwa pernikahan yang tidak tercatat oleh negara dianggap Ilegal, mungkin saja sah menurut agama, tetapi tidak sah menurut Hukum ${ }^{6}$. Selanjutnya mengenai jumlah perkara yang masuk ke Pengadilan Negeri Jambi selama tahun 2016, beserta putusan perkaranya dapat dilihat pada Tabel V di bawah ini.

${ }^{6}$ Sri Warni Wati, Hakim Pengadilan Negeri Jambi, wawancara tanggal 22 Agustus 2017 
Tabel V

Perkara KDRT Tahun 2016 PN Jambi

\begin{tabular}{|c|c|c|c|c|}
\hline \multirow{2}{*}{ No } & \multirow{2}{*}{ No Perkara } & \multirow{2}{*}{ Klasifikasi Perkara } & \multicolumn{2}{|l|}{ Status Perkara } \\
\hline & & & Tahapan & Status \\
\hline 1 & 166/Pid.sus/2016 & Pasal 44 (1) (4) UU No 23/2004 & Putus 2 bulan penjara & Inkrah \\
\hline 2 & 203/Pid.sus/2016 & Pasal 49 UU No.23/2004 & Putus Bebas & Kasasi \\
\hline 3 & 348/Pid.sus/2016 & Pasal 44 (1) (4) UU No 23/2004 & Putus 5 Bulan Penjara & Inkrah \\
\hline 4 & 399/Pid.sus/2016 & Pasal 44 (1) (4) UU No 23/2004 & $\begin{array}{l}\text { Putus } 1 \text { Tahun } 6 \text { Bulan } \\
\text { Penjara }\end{array}$ & Inkrah \\
\hline 5 & 541/Pid.sus/2016 & Pasal 44 (1) (4) UU No 23/2004 & Putus 1 Tahun & Inkrah \\
\hline 6 & 566/Pid.sus/2016 & Pasal 44 (1) (4) UU No 23/2004 & Putus 1 Tahun & Inkrah \\
\hline 7 & 567/Pid.sus/2016 & Pasal 44 (1) (4) & $\begin{array}{l}\text { Putus } 1 \text { Tahun } 6 \text { Bulan } \\
\text { Penjara }\end{array}$ & Inkrah \\
\hline 8 & 639/Pid.sus/2016 & Pasal 44 (1) (4) UU No 23/2004 & Putus 8 Bulan Penjara & Inkrah \\
\hline 9 & 640/Pid.sus/2016 & Pasal 49 & Putusan & $\begin{array}{c}\text { Laporan } \\
\text { dicabut }\end{array}$ \\
\hline 10 & 711/Pid.sus/2016 & Pasal 44 (1) (4) UU No 23/2004 & Putus 7 Bulan Penjara & Inkrah \\
\hline 11 & 718/Pid.sus/2016 & Pasal 44 (1) (4) UU No 23/2004 & $\begin{array}{l}\text { Putus } 1 \text { Tahun } 4 \text { Bulan } \\
\text { Penajra }\end{array}$ & Inkrah \\
\hline 12 & 731/Pid.sus/2016 & Pasal 44 (1) (4) UU No 23/2004 & Putus 2 Tahun Penjara & Inkrah \\
\hline 13 & 733/Pid.sus/2016 & Pasal 44 (1) (4) UU No 23/2004 & Putus 7 Bulan Penjara & Inkrah \\
\hline 14 & 734/Pid.sus/2016 & Pasal 44 (1) (4) UU No 23/2004 & Putus 9 Bulan Penjara & Inkrah \\
\hline 15 & 741/Pid.sus/2016 & Pasal 44 (1) (4) UU No 23/2004 & $\begin{array}{l}\text { Putus } 3 \text { Bulan } 25 \text { Hari } \\
\text { Penjara }\end{array}$ & Inkrah \\
\hline 16 & 939/Pid.sus/2016 & Pasal 44 (1) (4) UU No 23/2004 & $\begin{array}{l}\text { Putus } 1 \text { Tahun } 4 \text { Bulan } \\
\text { Penjara }\end{array}$ & Inkrah \\
\hline 17 & 958/Pid.sus/2016 & Pasal 44 (1) (4) UU No 23/2004 & Putus 10 Bulan Penjara & Inkrah \\
\hline 18 & 1209/Pid.sus/2016 & $\begin{array}{l}\text { Pasal } 44 \text { (1) UU no } 23 / 2004 \text { dan } \\
\text { Pasal } 351 \text { KUHP }\end{array}$ & Putus 1 Tahun Penjara & Inkrah \\
\hline
\end{tabular}

Sumber data Pengadilan Negeri Jambi

Tabel VI

Perkara KDRT Sampai Juli 2017 PN Jambi

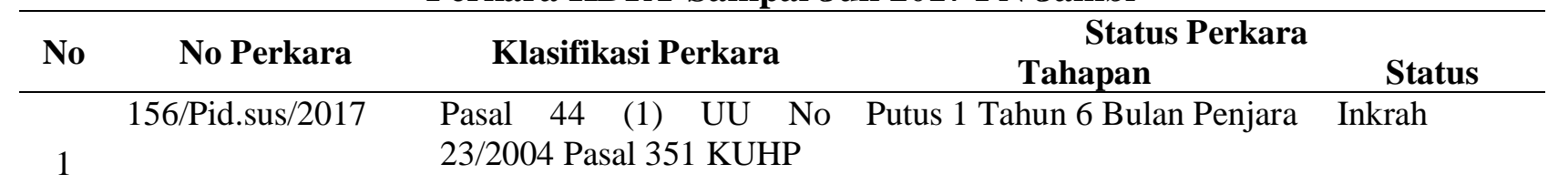

180/Pid.sus/2017

Pasal 44 (1) Pasal 80 (3) Putus 11 tahun Penjara

Inkrah

2

UU PA No 35/2004

3

221/Pid.sus/2017

4

5

308/Pid.sus/2017

504/Pid.sus/2017

586/Pid.sus/2017

6

597/Pid.sus/2017

Pasal 44

(3) UU No Proses Persidangan 23/2004, Pasal 181 KUHP

Inkrah

Pasal 44 (1) (4)

Putus 1 Tahun 3 Bulan Penjara

Inkrah

Pasal 44 (1)

(4) UU No

Putus 1 Tahun 3 Bulan Penjara

Laporan 23/2004

(4) UU No Putus 1 Tahun 3 Bulan Penjara

23/2004

Dicabut

Tuntutan

Tidak Dapat

Diminta

Tuntutan

Tidak Dapat

Diminta

Perlindungan Hukum terhadap Perempuan Korban Kekerasan dalam Rumah Tangga dalam Sistem Peradilan Pidana di Kota Jambi 


\begin{tabular}{lllll}
\hline $690 /$ Pid.sus/2017 & Pasal 44 (1) 45 (1) UU No & Proses Persidangan & Tuntutan \\
& $23 / 2004$ & & Tidak Dapat \\
& & Diminta \\
& & Tuntutan \\
9 & $701 /$ Pid.sus/2017 & $\begin{array}{l}\text { Pasal } 44 \text { (2), (1) UU No 23 } \\
\text { /2004 / Pasal 80 (1) UU No } \\
\text { 35/2004 }\end{array}$ & $\begin{array}{l}\text { Tidak Dapat } \\
\text { Diminta }\end{array}$ \\
\hline
\end{tabular}

Ada beberapa hal yang menarik yang terdapat dari Tabel IV s/d Tabel VI diatas yaitu putusan yang pertama putusan bebas dalam perkara No 46/Pid.sus/2015 PN Jambi. Serta perkara No 203/Pid.sus/2016/PN Jambi. Menurut Nirnala Dewi SH, dari sudut pandang Jaksa Penuntut Umum bahwa putusan hakim tersebut tidaklah tepat, karena berdasarkan pembuktian, Terdakwa (Pelaku Kekerasan) dalam Rumah Tangga telah terbukti bersalah melanggar Pasal 44 ayat (1) Undang-undang No 23 Tahun 2004.

Perbedaan pendapat dalam menilai suatu perkara adalah merupakan hal yang biasa, tetapi kami hakim mempunyai keyakinan sendiri untuk menentukan, bersalah atau tidaknya seseorang, dan apakah perbuatan tersebut merupakan perbuatan pidana atau tidak, demikian pernyataan yang disampaikan oleh Ibu Anissa B, SH. $\mathrm{MH}^{7}$., permasalahan lain yang menjadi pertanyaan adalah apakah perlindungan hukum terhadap korban KDRT secara represif sudah terpenuhi jika pelaku atau terdakwa di putus bebas?, untuk menjawab permasalahan ini memerlukan penelitian lebih lanjut karena ini menyangkut permasalahan lain yaitu berupa rasa keadilan.

Hal menarik lain yang kedua yang peneliti temukan yaitu putusan terberat pada perkara no 180/Pid.sus/2017/PN Jambi

7 Annisa B, SH,MH, Hakim Pengadilan Negeri Jambi, wawancara 22 Agustus 2017
Terdakwah di putus 11 (sebelas) tahun karena telah terbukti dakwaan kesatu melanggar Pasal 44 ayat (3) UU No. 23/2004 dakwaan ke dua Pasal 80 ayat (3) Undang-undang No. 23 Tahun 2002 tentang perlindungan anak tidak pula dibuktikan lagi, perkara ini displit dengan dengan perkara No. 221/Pid.sus/2017 PN Jambi namun perkara ini masih dalam proses persidangan atau belum ada putusan. kedua pelaku ini adalah suami istri yang merupakan orang tua dari korban Bella Ardyanti Binti Tabroni, seorang anak perempuan yang berusia 5 Tahun, meninggal karena di aniaya oleh bapak tirinya, dan ternyata ibu kandungnya turut membantu menguburkan jenazah anak nya dengan cara yang sangat tidak layak.

Hal ketiga yang menarik perhatian adalah perkara No. 640/Pid.sus/2016/PN Jambi dimana hakim membuat putusan yang menyebutkan bahwa laporan di cabut (berkas perkara dicabut), dan perkara No.504/Pid.sus/2017/PN Jambi juga putusan hakim menyebutkan bahwa laporan dicabut, serta perkara No 586/Pid.sus/2017/PN Jambi dimana isi putusan hakim menyebutkan bahwa tuntutan tidak dapat dipidana. ketiga macam putusan perkara ini tentunya memerlukan penelitian dan penganalisaan lebih lanjut, jika benar terbukti adanya korban KDRT maka tindakan pencabutan berkas adalah hal yang tidak sepatutnya terjadi. Pendapat ibu hakim Sri Warni Wati tentang hal ini, sebagaimana yang disampaikan menyebutkan bahwa 
perkara yang dicabut dapat dilakukan di karenakan beberapa hal, bisa saja jaksa penuntut umum selalu menunda-nunda tuntutannya, atau jaksa tidak dapat menghadirkan terdakwa di persidangan, atau terjadi kesalahan dalam mendakwakan perbuatan pidana sehingga hakim memberikan putusan sela bahwa eksepsi diterima, atau juga bisa terjadi karena korbanlah yang menarik perkaranya disebabkan telah berdamai dengan pelakunya, ketentuan ini dapat terjadi dalam perkara delik aduan ${ }^{8}$

Dilihat dari stelsel hukum pidana, tindak Kekerasan Dalam Rumah Tangga ini adalah tindak kekerasan pada umumnya sebagaimana diatur dalam Kitab Undang-Undang Hukum Pidana (KUHP) yakni sebagai tindak pidana penganiayaan, kesusilaan, serta penelantaran orang yang perlu diberi nafkah dan kehidupan.

Penyelesaiannya kekerasan dalam rumah tangga harus dilakukan secara komprehensif, melalui proses sosial, hukum, psikologi, kesehatan, dan agama, dengan melibatkan berbagai disiplin, lintas, institusi dan lembaga.

Bentuk perlindungan Korban KDRT atau bahkan lembaga pemberi perlindungan itu sendiri belum tentu memahami bagaimana perlindungan itu didapatkan dan bagaimana diberikan. Bagi korban yang status sosialnya lebih tinggi atau institusi dan lembaga yang tugas dan fungsinya selaku penegak hukum, tentu persoalan mendapatkan dan atau memberikan perlindungan

${ }^{8}$ Sri Warni Wati, SH. MH, Hakim Pengadilan Negeri Jambi, wawancara, 22 Agustus 2017 itu bukanlah masalah. Tetapi bagi institusi dan lembaga di luar itu, perlu mendapatkan pengetahuan dan keterampilan yang cukup. UU PKDRT secara selektif membedakan fungsi perlindungan dengan fungsi pelayanan. Artinya tidak semua institusi dan lembaga itu dapat memberikan perlindungan apalagi melakukan tindakan hukum dalam rangka pemberian sanksi kepada pelaku. Perlindungan oleh institusi dan lembaga nonpenegak hukum lebih bersifat pemberian pelayanan konsultasi, mediasi, pendampingan dan rehabilitasi. Artinya tidak sampai kepada litigasi. Tetapi walaupun demikian, peran masing-masing institusi dan lembaga itu sangatlah penting dalam upaya mencegah dan menghapus tindak Kekerasan Dalam Rumah Tangga.

Selain itu, UU PKDRT juga membagi perlindungan itu menjadi perlindungan yang bersifat sementara dan perlindungan dengan penetapan pengadilan serta pelayanan. Perlindungan dan pelayanan diberikan oleh institusi dan lembaga sesuai tugas dan fungsinya masing-masing:

1. Perlindungan oleh kepolisian berupa perlindungan sementara yang diberikan paling lama 7 (tujuh) hari, dan dalam waktu $1 \mathrm{X}$ 24 jam sejak memberikan perlindungan, kepolisian wajib meminta surat penetapan perintah perlindungan dari pengadilan. Perlindungan sementara oleh kepolisian ini dapat dilakukan bekerja sama dengan tenaga kesehatan, sosial, relawan pendamping dan pembimbing rohani untuk mendampingi korban. Pelayanan terhadap 
korban KDRT ini harus menggunakan ruang pelayanan khusus di kantor kepolisian dengan sistem dan mekanisme kerja sama program pelayanan yang mudah diakses oleh korban. Diharapkan agar Pemerintah dan masyarakat perlu segera membangun rumah aman (shelter) untuk menampung, melayani dan mengisolasi korban dari pelaku KDRT. Sejalan dengan itu, kepolisian sesuai tugas dan kewenangannya dapat melakukan penyelidikan, penangkapan dan penahanan dengan bukti permulaan yang cukup dan disertai dengan perintah penahanan terhadap pelaku KDRT.

2. Perlindungan oleh advokat diberikan dalam bentuk konsultasi hukum, melakukan mediasi dan negosiasi di antara pihak termasuk keluarga korban dan keluarga pelaku (mediasi), dan mendampingi korban di tingkat penyidikan, penuntutan, dan pemeriksaan dalam sidang pengadilan (litigasi), melakukan koordinasi dengan sesama penegak hukum, relawan pendamping, dan pekeda social (kerja sama dan kemitraan).

3. Perlindungan dengan penetapan pengadilan dikeluarkan dalam bentuk perintah perlindungan yang diberikan selama 1 (satu) tahun dan dapat diperpanjang. Pengadilan dapat melakukan penahanan dengan surat perintah penahanan terhadap pelaku KDRT selama 30 (tiga puluh) hari apabila pelaku tersebut melakukan pelanggaran atas pernyataan yang ditandatanganinya mengenai kesanggupan untuk memenuhi perintah perlindungan dari pengadilan. Pengadilan juga dapat memberikan perlindungan tambahan atas pertimbangan bahaya yang mungkin timbul terhadap korban.

4. Pelayanan tenaga kesehatan penting sekali artinya terutarna dalam upaya pemberian sanksi terhadap pelaku KDRT. Tenaga kesehatan sesuai profesinya wajib memberikan laporan tertulis hasil pemeriksaan medis dan membuat visum et repertum atas permintaan penyidik kepolisian atau membuat Surat keterangan medis lainnya yang mempunyai kekuatan hukum sebagai alai bukti.

5. Pelayanan pekerja sosial diberikan dalam bentuk konseling untuk menguatkan dan memberi rasa aman bagi korban, memberikan informasi mengenai hak-hak korban untuk mendapatkan perlindungan, serta mengantarkan koordinasi dengan institusi dan lembaga terkait.

6. Pelayanan relawan pendamping diberikan kepada korban mengenai hakhak korban untuk mendapatkan seorang atau beberapa relawan pendamping, mendampingi korban memaparkan secara objektif tindak KDRT yang dialaminya pads tingkat penyidikan, penuntutan dan pemeriksaan pengadilan, mendengarkan dan memberikan penguatan secara psikologis dan fisik kepada korban.

7. Pelayanan oleh pembimbing rohani diberikan untuk memberikan penjelasan mengenai hak, kewajiban dan memberikan penguatan iman dan takwa kepada korban. 


\section{SIMPULAN}

Undang-Undang

Penghapusan Kekerasan Dalam Rumah Tangga membedakan Fungsi Perlindungan dengan Fungsi Pelayanan, dan berdasarkan hasil penelitian kedua fungsi tersebut belumlah optimal dilaksanakan, artinya tidak semua institusi dan lembaga itu dapat memberikan perlindungan apalagi melakukan tindakan hukum dalam rangka pemberian sanksi kepada pelaku. Perlindungan hukum terhadap korban KDRT ini masih bersifat represif, penerapan hukum berupa penjatuhan pidana, masih terdapat beberapa putusan yang belum memenuhi kepastian hukum.

\section{Rekomendasi}

Upaya menghapus KDRT di muka bumi Indonesia adalah perjuangan panjang bangsa ini, khususnya kaum perempuan yang rentan menjadi korban KDRT. Perempuan dalam rumah tangga harus mendapat rasa aman, tenteram, adil dan bermartabat bagi keluarga dan bangsa Indonesia, oleh karenanya.

1. Perlindungan hukum dalam bentuk yang preventif haruslah di optimalkan oleh pemerintah dan semua pihak yang sangat peduli dengan perkembangan kehidupan perempuan, salah satunya adalah sosialisasi/penyuluhan hukum lebih maksimal kepada masyarakat dan aparat penegak hukum tentang penghapusan tindakan kekerasan dalam rumah tangga yaitu mengenai upaya hukum yang dilakukan baik perdata maupun pidana jika terjadi tindak kekerasan dalam rumah tangga.

2. Masyarakat juga perlu disosialisasikan bahwa setiap orang yang mengetahui adanya perkara kekerasan dalam rumah tangga merekapun berhak untuk menyampaikan kepada pihak yang berwajib atau lembaga-lembaga yang mengurusi masalah perempuan, agar tindak kekerasan dalam rumah tangga tidak terjadi berulang-ulang.

\section{DAFTAR PUSTAKA}
A. Ridwan Halim, Hukum Pidana Dalam Tanya Jawab, Ghalia Indonesa, Jakarta, 1984.

Andi Hamzah, Penegakan Hukum, Sinar Grafika, Jakarta, 2005.

Arif Gosita, Masalah Korban Kecelakaan, Kumpulan Karangan, Jakarta: Akademika Presindo, 1983

Bambang Poernomo, Azas-azas Hukum Pidana, Ghalia Indonesia, Jakarta, 1982.

Barda Nawawi Arief, Masalah Penegakan Hukum dan Kebijakan Hukum Pidana dalam Penanggulangan Kejahatan, , Jakarta: Kencana Prenada Media Group2007,

Departemen Pendidikan dan Kebudayaan, Kamus Besar Bahasa Indonesia, Balai Pustaka, Jakarta, 1990.

Dikdik M Arief Mansur dan Elisatris Gultom, Urgensi Perlindungan Korban Kejahatan (Antara Norma dan Realita), Jakarta : PT. Radja Grafindo Persada, 2006

EY Kanter dan SR Sianturi, Azasazas Hukum Pidana Di Indonesia dan Penerapannya, Alumni ARM-PTIB4, Jakarta, 1982.

Herkutanto, "Kekerasan Terhadap Perempuan dan Sistem Hukum : Pendekatan. dari Sudut Pandang Kedokteran," dalam Tapi Omas Ihromi 
dkk, Penghapusan

Diskriminasi Terhadap Wanita, Alumni, Bandung, 2006.

Muladi dan Barda Nawawi, Teoriteori dan Kebijakan Pidana, Alumni, Bandung,

1984

P.A.F. Lamintang, Hukum

Penitensier Indonesia, CV.

Armico, Bandung, 1984

Rika Saraswati, Perempuan dan

Penyelesaian Kekerasan

Dalam Rumah Tangga,

Bandung; Citra. Adytia, 2006.

Satochid Kartanegara, Hukum

Pidana, Bagian Satu,

Kumpulan Kuliah, Balai

Lektur Mahasiswa, Jakarta, 1987.

Soer ono Soekanto, Faktor-faktor yang Mempengaruhi Penegakan Hukum, Rajawali, Jakarta,1983.

R. Wirjono Prodjodikoro, Hukum Acara Pidana Di Indonesia, PT. Bale, Bandung, 1990,

Republik Indonesia, UndangUndang Nomor 1 Tahun 1974 tentang Perkawinan, Jakarta, Sinar Grafika, 2006.

Republik Indonesia, UndangUndang Nomor 23 Tahun 2004 Tentang Penghapusan Kekerasan Rumah Tangga, Jakarta Sinar Grafika, 2006.

Republik Indonesia, UndangUndang Nomor 13 Tahun 2006 Tentang

Perlindungan Sanksi dan Korban , Jakarta, Sinar Grafika, 2006 